\title{
Ratoon Rice: A Climate and Resource Smart Technology
}

\author{
R.B. Negalur ${ }^{1 *}$, G.S. Yadahalli ${ }^{2}$, B.M. Chittapur ${ }^{3}$, G.S Guruprasad ${ }^{4}$ and G. Narappa $^{5}$ \\ ${ }^{1}$ AICRP on Weed Management, ${ }^{2}$ Senior Farm superintendent, \\ MARS, UAS Raichur, Karnataka, India \\ ${ }^{3}$ AEEC, Koppal, UAS Raichur, Karnataka, India \\ ${ }^{4}$ Agricutural Entomology, AICRP on Rice, ARS, Gangavathi, UAS Raichur, Karnataka, India \\ ${ }^{5}$ KVK, Gangavathi, UAS Raichur, Karnataka, India \\ *Corresponding author
}

\begin{abstract}
A B S T R A C T

\begin{tabular}{|l|}
\hline Ke y w o r d s \\
Rice ratooning, \\
Regenerating tillers, \\
Varietal response \\
and management \\
practices.
\end{tabular}

Rice (Oryza sativa L.) is a main staple for human consumption all over the world. There is ever increasing demand for rice with increasing population and that too it has to be produced on the same stretch of land or less. Secondly, in many of the rice-rice cropping areas the second crop of rice of late is becoming doubtful due to reduced possibility of season-long availability of water for the succeeding crop due to climate change impacts. Energy is the other critical input. Under such circumstance traditional practice of ratooning offers hope as a climate and resource smart technology. Ratooning in rice offers an opportunity to increase cropping intensity per unit area because of its shorter growth duration than the main crop as it could be grown with 50\% less labour, $60 \%$ less water and at less cost than the main crop to produce not less than $50 \%$ of the main crop yield. The production cost is due to the minimized cost on land preparation, transplanting and crop maintenance. Ratooning, because of its short growth duration also fits well in rainfed areas on residual moisture. Besides these advantages, the success of ratoon rice in the USA and China on commercial scale, and availability potential rice cultivars these days have renewed the interest in ratoon rice culture. The article, therefore, discusses the state of art, research advances and way forward.
\end{abstract}

\section{Introduction}

Rice (Oryza sativa L.) is considered as the 'global grain' as it is the second largest source of food to many people especially in Asia (Niyaki et al., 2010). It is the major staple for more than half of the global population. The world's total estimated area under rice production is $159 \mathrm{M}$ ha with a production of 670 MMT with an average yield of $3889 \mathrm{~kg}$ ha $^{-1}$ (Anon., 2011). Out of 2234 calories day ${ }^{-1}$ capita $^{-1}$ food intake, rice accounts for 30 per cent in Indian and it could be as high as $75 \%$ of the total calories intake for more than 3 billion Asians (Khush, 2004). India with $42.50 \mathrm{M}$ ha area and 100.12 MMT of production with a productivity of $2400 \mathrm{~kg} \mathrm{ha}^{-1}$ stands second after China (Anon., 2015) where rice continues to hold the key to sustain food production by contributing 20-25\% of agriculture and assures food security in India for more than half of the total population (Anon., 2012).

Nevertheless, increase of food production is the most emerging challenge of new century, 
especially in developing country due to unhindered population explosion in the face of dwindling resources and inclement climate. So far substantial production use to accrue from second crop of rice in the tropics, but the production of a second rice crop is becoming difficult due to failure of rains and consequent lower water in the reservoirs and underground aquifer. For instance, for the last two years second rice crop is banned in the Tunga Bhadra Project irrigation command in Karnataka due failure of monsoon and the little water available in the reservoir is reserved for drinking. There is also no guarantee in the coming years that the situation would improve in view of changing climate and even if the second crop is possible it cannot be rice considering its water requirement provided technologies like rotooning are relooked in to as resource use and climate smart technology. Harvesting regrowth of planted crop after main crop harvest is called rationing. In rice it is considered an alternative for double rice cropping because of its short growth duration, low water requirement and high water use efficiency. A ratoon crop may also fit well in rainfed areas on residual moisture left after wet season rice crop or in irrigated areas with limited duration of available water or growing season. Harvesting of rice twice from the same single crop is practiced in the United States, Swaziland, India, Thailand, Taiwan, the Philippines and China (Nakano and Morita, 2007).

Success of ratoon cultivation in the USA and China on commercial scale and high ratoon yield potential of new rice cultivars have generated new interest in ratoon culture some time back (Chauhan, 1988) but scientific efforts lack consistency. Here, the production costs are lower than main crops due to the minimized cost for land preparation, transplantating and crop maintenance (Bond and Bollich, 2006; Harrell et al., 2009).
However, performance of ratoon apart from varietal potentiality depends on tillering behavior, duration of main crop, plant height, cultural practices, land preparation, spacing, seedling age, harvesting time of main crop, cutting height, fertilizer, water and pest and disease management and also external factors like temperature and light intensity. The amount of Total Carbohydrate Content (TAC) in the stem base, at early growth also found to influence ratoon growth. If everything is optimum not less than 50 per cent of main crop yield is well assured with less than $50 \%$ of the resources used in the main crop.

Further, the technology generates interest as Asian rice-growers are considering moving from highly labour-intensive methods to less labour intensive methods due to general rise in the cost of labour and shortage. The Philippines government is promoting rice ratooning as a means of attaining national self-sufficiency in rice (Sun Star newspaper, 17 July 2013). The approach is also being promoted in Pakistan (Hafeez ur Rehman et al., 2013). Ratooning offers a potential to obtain increased production at relatively low cost. In the 1960s the opportunity cost of rice production in China and much of Southeast Asia was probably close to zero. In most of the region, it is now much above that level, a situation reflected in substantial short term circular migration by rice growers and in some cases production being at economic loss, as was already reported in parts of Peninsular Malaysia in the 1960s. Because tillage, preparation of nursery, sowing in nursery, and transplanting may require 25-30 $\%$ of labour input per crop, any system of crop production that can reduce such inputs, without any drastic yield reduction is very desirable, as the cost of labour will inevitably continue to rise (Ronald, 2014).

Rice ratooning offers an opportunity to increase cropping intensity per unit area 
because of its sorter growth duration than main crop. On an average, ratoon rice gives a yield roughly equivalent to $40-50 \%$ as that of main crop with $40 \%$ reduction in crop duration (Krishnamurthy, 1988). In addition, a ratoon crop can be grown with $50 \%$ less labour and $60 \%$ less water than the main crop (Oad et al., 2002). Presuming that farm labour costs are inevitably rising and also mobility of labour force is increasing, there is a need to control the costs of rice production. Ratooning substantially reduces the labour cost of traditional methods involving nursery preparation and transplanting, probably by around 50 to 60 percent per crop (Flinn and Mercado, 1988). Then why can't try this?

Globally, the consumption of rice per person has levelled out the late 1980s (Rejesus et al., 2012) though demand in Africa continues to rise. Estimates of very large increases in demand are probably not well founded. Fageria (2007), for example, estimated a requirement of 60 percent more rice by 2025 , just over a decade away. The reality is that since the 2007-08 season, global rice stocks have tended to rise, reaching close to an estimated 35 percent of annual global consumption by 2013-14 (FAO Rice Monitor, July 2013). This will give something of a breathing space to develop alternatives to the region's current highly labour-intensive methods. Considering all the above, an attempt is made here to enlighten rice growers and the scientists on this traditional practice as climate and resource use smart technology.

\section{Factors influencing ratoon performance}

\section{Varieties}

Main and ratoon crops are exposed to different day length, temperature and sunlight conditions hence varietal adoptability is the major factor for ratoon success. Varietal ability or potential, plant type and responsiveness to nitrogen are the most considered plant characters on which the success of ratoon largely depends (Poehlman, 1976). Studies in the early decades revealed that, cvs. IR2061- U23, IR2145-20-4 and IR1924-36-22 possessed high ratooning ability (Haque, 1975). In India C3810, Ratna, CR20-66, and CR156-5021-207 showed superiority in ratooning and yield ability (Das and Ahmed, 1982). During the same period in Karnataka, Mahadevappa (1988) first time ventured on ratooning and emphasized importance of selection of right cultivar. He reported that cv. 5-684 produced $2.7 \mathrm{t} \mathrm{ha}^{-1}$ in main and a $1.0 \mathrm{t} \mathrm{ha}^{-1}$ in ratoon and the latter came to harvest by about $65 \%$ of the main crop duration. Subsequently, Prakash and Prakash (1988) at Siruguppa, Karnataka identified cvs. BPT-2226, BPT-2685, IET7431 and KMS-5914 for ratooning in irrigation command. Long duration cv. Intan has been recommended for ratooning in hilly areas of Karnataka under rainfed transplanted condition (Anon., 1987) while early varieties viz., IET-7564 and Amruth performed better than medium to late duration varieties under drill sown condition (Anon., 1992). However, the initial experiences under rainfed conditions at Mugad, Karnataka were not encouraging (Anon., 1992). In Tamil Nadu, Palchamy et al., (1990) reported that the variety Bhavani fared better than Ponni and IR-20.

Chauhan et al., (1985) observed that tillering depends on the nutrition of main crop roots at least 21 days after harvest. Ratoon grain yield and total dry matter are positively correlated with stem thickness, stubble carbohydrate and delayed leaf senescence in the main crop with ratoon crop leaf area and chlorophyll content (Balasubramanian et al., 1992). Bollich and Turner (1988) indicated that higher the ratoon yield, the better the millings yield. Despite lower grain weight ratoon crop seeds germinate as well as the main crop seeds 
(Rosamma et al., 1985). Nagaraja and Mahadevappa (1986) observed comparable performance of main and ratoon crops, however, the seed quality of main and ratoon crop varied with variety and that viability in ratoon crop seeds deteriorated faster than it did in main crop seeds.

Reddy and Mahadevappa (1988) reported that photosensitive variety Intan was more suitable for ratooning in hilly areas of Karnataka, while Roy et al., (1988) observed that photoperiod sensitive rice varieties in deep water area of Eastern India help reduce crop loss from frequent floods of rainwater. In China, some rice hybrids revealed high grain yields and had high ratooning ability and the hybrid Zaishelgyou produced the highest main and ratoon crop yields resulting in a significantly higher total yield $\left(11.0 \mathrm{t} \mathrm{ha}^{-1}\right)$ (Oad et al., 2002). However, despite lower ratoon yield Aiyou 1, was considered as most suitable for ratooning than Aiyou 2, the yield of which was $2.6 \mathrm{t} / \mathrm{ha}$, because wider adoptability and higher ratooning ability of Aiyou 1, whereas, Aiyou 2 was found susceptible at flowering stage (Sun Xiaohui et al., 1988). Hassan et al., (2013) also concluded that choice of cultivar is important. They observed cvs. Hashemi and Hassani with means of 364.05 and $146.92 \mathrm{~g} / \mathrm{m}^{2}$, respectively were best suited for ratooning.

Among different maturity groups of lowland genotypes, Santos et al., (2003) realized 59\% in late maturing types and a disappointing $39 \%$ in medium-term types of the main crop optimum. Comprehending 124 experiments, Chauhan et al., (1988) concluded that cv. Intan, with 2.3 to $7.7 \mathrm{t} \mathrm{ha}^{-1}$ in India, cv. Milbuen 5 from the Philippines with $5.6 \mathrm{t} \mathrm{ha}^{-1}$ and IR 8 with 8.2 and $8.7 \mathrm{t} \mathrm{ha}^{-1}$, as outstanding cultivars. Moderate ratoon yields were obtained from IR 42 and IR 97523-71-32 , which ranged from 33 to 49 percent of the main crop yields while the remaining ten cultivars produced ratoon yields less than 10 percent of the main crop yields (Chauhan et $a l ., 1988)$. In Ethiopia of the two cultivars, IR 8 out yielded IR 5 for both the main and ratoon crops and yield ranged from 6.3 to 8.7 $\mathrm{t} \mathrm{ha}^{-1}$, the yield levels, however, are suspect.

Thus, Success of ratoon and quantum of yield realization depends on cultivar characteristics such as duration, stem thickness, stubble carbohydrate, delay in leaf senescence and nutrition of main crop roots at ratoon sprouting.

\section{Crop establishment}

The effect of direct seeding and transplanting on ratooning ability has not been studied extensively, but good ratoon yields from drilled crops have been reported from Texas (Evatt, 1966 and Evatt and Beachell, 1960). One of the advantages of direct seeding for ratoon cropping is the large number of plants per unit area, each of which will only need to grow a few ratoon tillers to produce high number of tillers/unit area. In Indonesia, dryseeded IR30 produced a successful ratoon yielding 1.9-2.8 $\mathrm{t} \mathrm{ha}^{-1}$ (Pandang et al., 1977) while adjacent direct transplanted rice crop suffered drought stress and yielded less than the ratoon crop. On the contrary, Hassan et al., (2013) observed significant difference due to planting methods, and ratoon yield was the maximum $\quad\left(\mathrm{M}=139.08 \mathrm{~g} / \mathrm{m}^{2}\right) \quad$ with transplanting.

Varghese and Patil (1991) reported that even under high rainfall areas of coastal Maharashtra, under lowland conditions summer planted crop gave similar ratoon crop yields as that of wet season planted rice. De datta and Bernasor (1988) noticed that higher the temperature, the grater the ratoon plant height and percentage of tillers at early stages of development, whereas, in Karnataka, excellent yields were obtained from both the 
main crop and the ratoon (Krishnamurthy, 1988). Main crop yields reportedly ranged between 8.7 and $11.8 \mathrm{t} \mathrm{ha}^{-1}$. In terms of percentage the ratoon yield ranged between 67 and 90 percent of the main-crop outturn where the main crop had been direct-seeded, compared with a range of ratoon yields between 59 and 78 percent of main crop yields where the main crop had been transplanted.

Nevertheless, further studies on comparisons of dry seeded and transplanted ratoon, so also the new cultures such as arobic rice and SRI (system of rice intensification) for ratoon performance are necessary for any generalization or recommendation to specific situations. In all, a good uniform plant stand is a prerequisite for a productive ratoon crop, irrespective of seeding or transplanting method or other method of establishment, but other management factors are equally important in determining ratoon performance.

\section{Land preparation}

Land preparation for the main crop is found to influence the performance and the success of ratoon crop as well (Parago, 1963). In that, ratoon crop grain yield is significantly influenced by tillage method. Ratoon plants grown after zero tillage yielded least, while plowing deeper increased culm elongation and panicles per plant, and plowing $25 \mathrm{~cm}$ deep gave higher grain yield than shallow tillage, however, plowing deeper than $25 \mathrm{~cm}$ tended to decrease ratoon crop viability (Hsieh et al., 1968; De Datta and Bernasor, 1988). The main crop that had been plowed and harrowed produced the highest $\left(1.1 \mathrm{t} \mathrm{ha}^{-1}\right)$ ratoon crop yield (Bahar and De Datta, 1977).

Further, De Datta and Bernasor (1988) reported good ratoon yields from drilled crops. At IRRI, also ratoon crop performance was significantly influenced by tillage method. Plowing followed by harrowing of the main crop land gave higher grain yield and panicle number in ratoon plants compared to main crop grown under zero tillage. Bahar and De Datta (1977) observed that the total rice grain yields were $11.7,11.4$ and $7.6 \mathrm{t} \mathrm{ha}^{-1}$ for transplanted, transplanted-direct seeded and transplanted ratooned cropping system and usual land preparation involving plowing followed by harrowing to main crop produced more tillers in the ratoon crop compared to zero tillage.

Parago (1963b) concluded that success of the ratoon crop is dependent principally on the thorough preparation of land for the main crop and decreased viability of ratoon was noticed with increase in plowing depth even though there was increase in elongation of culm, however, an increase of the number of panicles per plant was observed and plowing $25 \mathrm{~cm}$ deeper recorded higher grain yield compared to shallow tillage. However, tillage did not affect number of filled spikelets /panicle and number of missing hills even though plots with regular main crop land preparation tended to grow more ratoon tillers (Samson, 1980).

\section{Time of sowing/planting}

Main and ratoon crops are exposed to different day length, temperature and sunlight conditions at different planting date and there is little work in this aspect, which may influence ratoon crop performance (Chauhan, 1988). In Portuguese, the effect of main crop sowing time on ratoon growth duration and grain yield was studied using De Abriel, IR841-63-5, and IR899-55-6-4-6-1B following planting from 18 September to 22 February at 30 days intervals (Oliveira and Neto, 1979). Among all, the September seeding yielded the highest for all the three varieties. IR841-63-5 and IR899-55-6-4-6-1B ratooned successfully up to the November 
seeding, but grain yields declined sharply thereafter. In the US, Bollich and Turner (1988) observed that cultivars harvested by $15^{\text {th }}$ August usually produced a ratoon crop in $2 / 3$ to $3 / 4$ of the time needed for main crop. In the southern peninsular region of India, Mahadevapp et al., (1988) obtained good ratoon yields from several cold tolerant winter varieties planted in October.

Growth duration of ratoon crop did not show any consistent trend with delay in seeding. No ratoon was obtained after November seeding. In another study, Ramos and Dittrich (1981) also found that sowing date affected ratoon grain yield and September seeding yielded more than the October seeding. In all, low temperatures at late main crop growth prevented ratoon development. Thus, optimum planting varies in different locations and continents. In general, earlier planting is the season is the key to success.

\section{Effect of spacing}

Planting geometry is an important influencing factor as it determines main crop plant population. High main crop plant population increases tiller number/unit area, therefore increasing potential ratoon tiller number/unit area. However, that increase is not proportional to the increase in ratoon crop population because high plant density also increases the number of missing hills (Bahar and De Datta, 1977). At Madurai, Tamil Nadu, Srinivasan and Purushothaman (1990) reported that the spacing of $15 \mathrm{~cm} \times 10 \mathrm{~cm}$, $20 \mathrm{~cm} \times 10 \mathrm{~cm}$ and $25 \mathrm{~cm} \mathrm{x} 10 \mathrm{~cm}$ had no significant difference, however, $20 \mathrm{~cm}$ x 20 $\mathrm{cm}$ spacing produced optimum ratoon grain yield mainly because the number of missing hills at $20 \mathrm{~cm} \times 20 \mathrm{~cm}$ was significantly less than at $15 \mathrm{~cm} \times 15 \mathrm{~cm}$ and was equal with that of $25 \mathrm{~cm} \times 25 \mathrm{~cm}$ (Bahar and De Datta, 1977). Parago (1963) has had similar opinion. Interestingly, Altamarino (1959) obtained significantly higher ratoon yield with $10 \mathrm{~cm} \mathrm{x}$
$10 \mathrm{~cm}$ compared to spacings of $20 \mathrm{~cm} \mathrm{x} 20$ $\mathrm{cm}, 30 \mathrm{~cm} \times 30 \mathrm{~cm}$, and $40 \mathrm{~cm} \times 40 \mathrm{~cm}$. Closer spacing, however, requires more maincrop seed, time, and labor during planting.

Plant spacing affects the number of missing hills in the ratoon crop but grain yield may not be significantly affected (Bahar and De Datta, 1977). Spacing determines main crop plant population and a high main crop plant population increases the tiller number/unit area and also increases potentiality of ratoon tiller per unit area (Srinivasan, 1988), however, interaction between genotype and spacing plays important role. For instance, in IR-28 the optimum spacing for the best ratoon yield was $20 \mathrm{~cm}$ x $20 \mathrm{~cm}$ (Bahar and De Datta, 1977). At many instances, spacing significantly affected the yield of main crop but had no significant influence on yield of ratoon.

\section{Time of main crop harvest}

The maturity stage or time of cutting or harvesting of main crop is correlated with yield of main crop, number of auxiliary bud sprouting and number of productive panicles and ultimately the yield of ratoon crop. The stage of maturity at main crop harvest affects ratooning (Haque, 1975; Votong, 1975; Yang, 1958; Yang, 1940). The best harvesting time for good ratooning is when the culms are still greenish (Grist, 1965, Parago, 1963, Saran and Prasad, 1952). Stalks should be cut before the main crop is fully matured (Balasubramanian et al., 1970; Nagai, 1958) or at full maturity when the ratoon shoots have just begun to grow (Szokolay, 1956). Delaying main crop harvests for 44-56 days after flowering reduced ratoon crop growth duration (Votong, 1975). Ratoon growth duration, weight, height, and percentage of ratoon tillers declined if cutting was delayed by 10-20 days after heading (Ichii, and Kuwada, 1981). 
Ratoon traits improved slightly with early cutting at 30-40 days after heading, however, in a study when harvesting was done at 30, 35,40 and 45 days after main crop flowering no significant influence was noticed on ratoon performance (Haque, 1975, Reddy et al, 1979). In China, Xiong et al., (1991) observed that cutting date of main crops correlated with yield of main crop, number of axillary buds sprouting, and number of productive panicles and yield of ratoon crop. Cutting when the culms of main crop are still green is the best time to harvest for raising good ratoon crop (Parago, 1963b). However, Mahadevappa et al., (1988) reported that, as senescence is a varietal character, the harvesting time of main crop might depend upon the variety and the location where the crop is grown. In general, cutting the main crop to $25 \mathrm{~cm}$ height and harvesting 5 days earlier than optimum time was the best method for effective rationing, and cultivar, cutting height, and harvest time were interactive (Haque, 1975).

\section{Cutting height of main crop}

Stubble height determines the number of buds available for regrowth. The effect of cutting height also influenced ratoon vigour. Cutting to the ground level was suggested in the Philippines to prevent the growth of unproductive tillers (Parago, 1963b). Balasubramanian et al., (1970) opined that increasing the cutting height results in an increase of the ratoon straw yield but it will not affect grain yield. Some cultivars produced ratoon from higher nodes and others produced from the basal, and the latter are unaffected by cutting height (Volkova and Smetanin, 1971).

IR-28 and IR-2061-464-2 when cut at 5, 15 and $20 \mathrm{~cm}$ it was found that the number of tillers of both the varieties decreased as the cutting height increased (Bahar and De data, 1977). In India, Bardhan Roy and Mondal
(1982) reported that cutting height do not affect significantly the ratooning ability, reproductive tillers and yield of ratoon. The yield of Bhavani variety was $2.8 \mathrm{t} \mathrm{ha}^{-1}$ (50 per cent of its main crop yield), when it was cut at $15 \mathrm{~cm}$ from ground level (Srinivasan, 1988). Cultivars and cultural practices including cutting height and fertilizer management which provide a large quantity of reserves at harvest, may be advantageous for rice ratooning (Ichii, 1984).

Cutting height determines the origin of ratoon tillers and growth duration of ratoon (Sun Xiaohui et al., 1988). De Datta and Bernasor (1988) reported 15 to $20 \mathrm{~cm}$ above the ground as ideal cutting height while Zhang and Guo (1991) suggest a cutting height of 30-40 cm above the ground as optimum. Under rainfed conditions in which water needs to be retained in the field, the main crop should be cut at 15 $\mathrm{cm}$ height or more in order to minimize the number of missing hills in ratoon and to reduce weed growth (Vergara et al., 1988) Under drill sown condition at Mugad, Karnataka, $20 \mathrm{~cm}$ cutting height of main crop fared better than that of $10 \mathrm{~cm}$ (Anonymous 1992).

\section{Fertilizer management}

Fertilized plots produce better ratoon yields than unfertilized plots (Reddy and Pawar, 1959 and Yang, 1940). In other words, ratoon crop growth and yield is directly or indirectly affected by the soil fertility (Plucknett et al., 1978). Nitrogen significantly affects ratoon growth while phosphorus is important for good root development. Appropriate time of application, dosage and kind of fertilizer best suited for ratoon crop need thorough investigation, and it is wise to use quick acting fertilizers (Iso, 1954).

Applying $\mathrm{N}$ has been shown to increase ratoon grain yields (Bahar and De Datta, 1977; Chatterjee et al., 1982; Evatt and 
Beachell, 1960; Flinchum and Evatt, 1972; Parago, 1963; Quddus, 1981; Sanchez and Cheaney, 1973; Yang, 1940 and Zandstra and Samson, 1979; Shetty et al., 1993). It should be applied immediately after harvest of main crop to promote early sprouting (Bahar, 1976, Flinchum and Evatt, 1972 and Ishikawa, 1964). Even $\mathrm{N}$ management in main crop has substantial influence on subsequent ratoon. For instance, applying $\mathrm{N}$ fertilizer to the main crop 14 days before harvest increased sprouting rate by 10 per cent, however the practice found to decrease main crop grain yield (Hsieh and Young. 1959). Seventy five percent of the recommended amount of $\mathrm{N}$ for the main crop should be applied immediately after harvest of main crop to achieve good ratoon yields (Flinchum and Evatt, 1972), whether second and third fertilizer applications are recommended (Parago, 1963). Fertilizer should be placed close to the stubble rows to ensure rapid nutrient uptake and growth (Parago, 1963 and Plucknett et al., 1978).

Fertilizer effect depends on the inherent ratooning ability of the cultivar, and its ratooning vigor, ratoon type, and growth duration. Cultivars also differ in their response to $\mathrm{N}$ applied to the ratoon crop (Balasubramanian et al., 1970 and Reddy and Pawar, 1959). As ratoon yields increase, response to applied $\mathrm{N}$ also increases (Zandstra and Samson, 1979; Setty et al., 1993). Conflicting reports with regard to $\mathrm{N}$ fertilizer and crop maturity exist. If Beachell et al., (1961) observed delay in matureity due to $\mathrm{N}$ (Beachell et al., 1961) many others report no change in maturity time (Quddus, 1981 and Sanchez and Cheaney, 1973).

Fertilizer application may (Hsieh and Young, 1959) or may not affect tillering (Bahar and De Datta, 1977). Some observe that applying high amounts of $\mathrm{N}$ to the main crop reduces ratooning viability by weakening plants due to excessive growth (Hsieh et al., 1968). However, there are also reports suggesting increasing $\mathrm{N}$ level to ratoon $(60-100 \mathrm{~kg} / \mathrm{ha})$ correspondingly increase ratoon grain yield (Setty et al., 1993). Overall ratoon duration being small, split application of $90 \mathrm{~kg} \mathrm{ha}^{-1} \mathrm{~N}$ as a basal dose, at panicle initiation, early milk stage, late milk stage and 7-15 days before main-crop harvest did not significantly affect ratoon crop grain yield and tillers $\mathrm{m}^{2}$ (Quddus, 1981).

Ratoon crop plant height, panicle length, 1000-grain weight, filled and unfilled spikelets also remain unaffected by ratoon crop N application method (Sompaew, 1979). Similarly, no significant interaction between fertilizer application time and cutting height was observed, however, amount and application method in the main crop affected the ratoon crop (Quddus, 1981 and Samson, 1980). Deep placement of $\mathrm{N}$ in the main crop produced higher panicle density and 15\% higher ratoon grain yield than split application. In fact, split application delayed flowering, harvesting and produced lower leaf area index in the ratoon crop.

In trials at Siruguppa, Karnataka, India, under irrigated conditions Prakash et al., (1988) found that $50 \mathrm{~kg} \mathrm{~N} / \mathrm{ha}$ resulted in the most regenerated tillers per plant and the highest ratoon yields compared to Azolla only @2.5 t/ha and Azolla@ 2.5 t/ha + 25 kgN/ha. At same location, Setty et al., (1993) found that ratoon rice grain yield increased with increasing in $\mathrm{N}$ rates. Deep placement of $\mathrm{N}$ $(8-10 \mathrm{~cm})$ in the ratoon crop produced significantly higher yield than an equal amount of broadcast $\mathrm{N}$ and higher grain yield was associated with more panicles/plant, filled spikelets/panicle and more vigorous ratoon plants. Increasing $\mathrm{N}$ also increased plant vigor but at the same $\mathrm{N}$ level, the broadcast application treatment was less vigorous than the deep placement treatment 
(Quddus, 1981). Interestingly, soil incorporation immediately after harvest or top dressing 10 days after harvest did not significantly influence number of missing hills in the ratoon (Samson, 1980).

Applying $\mathrm{P}$ and $\mathrm{K}$ to the ratoon crop did not significantly affect ratoon grain yields. However, Chatterjee et al., (1982) reported that a ratoon crop yielded better with $20 \mathrm{~kg}$ $\mathrm{ha}^{-1} \mathrm{P}$ and $\mathrm{K}$. In fact, many reports suggest significant increase in ratoon yield with applying $\mathrm{P}$ to the main crop (Evatt, 1958, Flinchum and Evatt, 1972 and Mengel and Leonards, 1978). In general, a ratoon crop will grow if water alone is added, grain yield is significantly higher, if fertilizer is applied. To promote early and abundant ratooning which increases grain yield, it is important to apply fertilizer immediately after main crop harvest within 10 days and a dosage of 50-90 $\mathrm{kg} \mathrm{ha}^{-1}$ depending on cultivar potential and duration and deeper placement beside the stubble are important.

\section{Water management}

For proper growth and to promote ratooning, the field should be moist but not flooded for two weeks at the end of main-crop ripening. Draining the field several days after harvest also encourages ratooning. Irrigation water must be shallow in early ratooning stages, but irrigation is essential immediately after the first fertilizer application. One week later, the field should be drained and weeded, followed by intermittent irrigation. There occurs significant interaction between cutting height and rewatering time, when stubble are cut lower, delaying irrigation for four to six days is better than rewatering one day after cutting (Prashar, 1970). The study on time of drainage of main crop and rewatering the ratoon crop on grain yield revealed increased grain and dry matter yields of both main and ratoon crops by delayed harvest after draining the main crop (Votong, 1975). Draining the main crop increased ratoon panicles $\mathrm{m}^{-2}$ and decreased the percentage of missing hills and sterile florets.

However, draining the field during main crop harvest is not essential for good ratoon crop (Bahar, 1976). When the ratoon crop remained flooded, yield was $2.5 \mathrm{t} \mathrm{ha}^{-1}$ at 15 $\mathrm{cm}$ and zero at ground level cutting height (Bahar and De Datta, 1977). Ground level cutting with continuous $5-7 \mathrm{~cm}$ flooding produced very few ratoons. If plots are drained during main crop harvesting and irrigated 12 days after harvest, ground level and $15 \mathrm{~cm}$ cutting produced comparable grain yields. The number of missing hills increase as the time between harvest and rewatering is shortened. However, at $15 \mathrm{~cm}$ or higher cutting height, it is better if fields remained flooded because continuous flooding reduces weeds.

Water management did not significantly affect percentage of ratoon tillers or ratoon height when the crop was cut at 5 or $20 \mathrm{~cm}$ (Ichii, 1983), probably because ratooning ability depends largely on food reserves in the stem base and on temperature (Ichii, 1983). Many hills died when the crop was cut at ground level and water remained $5 \mathrm{~cm}$ deep. However, the effect of water management on ratoon grain yield and components is not studied much (Ichii, 1983). Ratoon tiller production did not increase 20 days after cutting. Different main-crop water regimes, such as deep drainage, open bunds, and standing water did not significantly affect the number of missing hills in the ratoon crop (Samson, 1980).

Providing shallow and permanent flooding immediately after main crop harvest is better than flushing for 3 weeks before flooding. All plots with immediate flooding yielded more than those that were flushed regardless of $\mathrm{N}$ 
rate (Mengel and Leonards, 1977 and Mengel, and Wilson, 1981). Ichii (1983) did not observe rapid growth with early flooding, but Mengel and Wilson (1981) reported that early flooding encouraged more rapid, uniform regrowth than delayed flooding and produced significantly better ratoon height and yield.

Some more studies are needed to evaluate the effect of the main crop water regime on ratooning. Water depth may affect the viability of ratoon tiller buds, but in deep water rice some cultivars ratoon even if the culm is submerged for several weeks. Draining the main crop at harvest is generally suggested to promote ratooning and prevent death of hills due to flooding. However, under rainfed situation where water has to be retained as much as possible, the main crop should be cut at $15 \mathrm{~cm}$ or higher to minimize the number of missing hills in the ratoon crop (Zandstra and Samson, 1979). Overall, water management seems to affect the ratoon crop to a considerable extent. More important is the interaction between cutting height and water management before and after main crop harvest. The appropriate combination of cutting height and rewatering time should be considered. Flooding with very short cutting can result in poor stands by increasing the number of missing hills whereas delayed watering would result in severe weed competition to the ratoon crop.

\section{Effect of growth regulators}

Significant differences are noticed between the plant characters of both main and ratoon crop, especially the plant height (Balasubramanian et al., 1970). For instance, effective ratoon tillers (Bahar and De Datta, 1977) are generally lower than in the main crop. Some ratoon crops found to produce more total tillers than the main crop (Bahar and De Datta, 1977, Quddus, 1981 and Samson, 1980), however, many of these remain unproductive (Balasubramanian et al., 1970 and Evatt, 1958). This is not desirable because here axillary buds continue their metabolic activity at the cost of grain filling. To obtain higher ratoon grain yields, it is imperative that percentage of productive tillers is increased. Growth regulators have been reported to stimulate growth and stem elongation and to inhibit lateral bud development (Leopold and Kriedemann, 1975), but information on their use to improve ratooning ability is very meager. Applying gibberellic acid (GA3), indole acetic acid (IAA), naphthalene acetic acid (NAA), or 2,4-dichloroc-phenoxyacetic acid $(2,4-D)$ at main crop flowering and late milk stage did not appreciably affect grain and other yield components of the ratoon crop. However, they all increased panicle number/hill (Quddus, 1981).

The effect of benzyladenine (BA), 2chloroethyl trimethyl ammonium chloride, $\mathrm{GA}_{3}$, kinetin and NAA on ratoon tillering depend on their concentration and time of application (Hou, 1983), but all growth regulators increased ratooning. Five ppm $\mathrm{GA}_{3}$ and 100 ppm BA induced bud sprouting most effectively. In general, foliar application of growth regulators at milk stage produced a higher percentage of sprouted buds than application at any other stage. Plant growth regulators generally do not significantly affect ratoon grain yield or other yield components, except panicles per hill. Grain yield was not increased because of high ratoon crop spikelet sterility (Hou, 1983).

\section{Pest and disease}

Pests assume significance in rice ratoon as insect damage can reduce or prevent ratooning (Yang, 1940). Ratoon crops may be heavily infested with stem borers, which can cause total crop loss (Evans, 1957). Heavy insect pest incidence on ratoon crop than on 
main crop has been reported (Grist, 1965). Ratoon rice often has high grassy stunt virus infection, while transplanted seedlings of the same age are virus free (Bahar and De Datta, 1977). Ratooning virus susceptible varieties may involve considerable risk of disease damage. In IR 36, stem rot significantly reduced the number of ratoon tillers (Samson, 1980). Cultivars with good ratooning ability and pest resistance, therefore, are needed in ratooning.

Ratoon crop is potentially at risk from insect pests because it extends the time rice is available as host (Dela Cruz and Litsinger, 1988). Nagaraju et al., (1988) reported that the important insect pests of ratoon rice are leaf and plant hopper, stem borers and leaf rollers. They also opined that application of insecticides once after main crop harvest and again at the flag leaf stage of the ratoon crop may reduce the incidence and thereby the virus incidence transmitted by them. Mew and Fabellar (1988) reported that if the main crop had systemic disease infections, the stubble is unlikely to produce any ratoon tillers, if the infections are late, with the diseases such as tungro, ratoon tillers may develop but subsequently succumb to the disease. Yellow dwarf, a disease caused by MLOs is often observed in ratoon crop probably because of its long latency in the rice plants (Mahadevappa et al., 1988). Anyway, the damage would be more if the cultivar used is a susceptible one unlike a rice-rice rotation where there is possibility to change the succeeding rice with resistant/tolerant one.

\section{Economics}

The studies on the economics of rationing are scarce. Krishnamurthy (1988) while studying the economics of ratooning of Intan in blastfree areas in Goorg district of Karnataka observed that average yield of Intan in the area was $3.5 \mathrm{t} \mathrm{ha}^{-1}$. He opined that if ratoon cropping were to be economical, it should yield at least $50 \%$ of the main crop (1.75 t/ha) then total returns from ratoon crop would significant and sizeable. Reviewing rice ratooning in the Dominican republic, Cuevas Perez (1988) reported that ratoon rice yield 92 and $52 \%$ of the $\mathrm{II}^{\text {nd }}$ planted crop yields in Jicome and Castanuelas, respectively. Production costs were similar across locations, although total costs tended to be higher in Jicome. Ratoon crop costs were less than those of planted crop. Ratoon crops cost productivity was 30.8 and $24.5 \mathrm{~kg} \mathrm{ha}^{-1} \mathrm{day}^{-1}$ compared with second planted crop productivity of 27.8 and $32.8 \mathrm{~kg} \mathrm{ha}^{-1} \mathrm{day}^{-1}$ in Jicome and Castanuelas, respectively.

While, Bollich and Turner (1988) in their report on commercial ratoon rice production in Texas, USA, opined that unit cost of production was inversely related to yield of both the main and ratoon cops. They concluded that there was distinct cost advantage in growing a ratoon crop, the unit cost of production for main and ratoon crop ranged between 233-275 and 176-227 $\$ \mathrm{t}^{-1}$, respectively.

\section{Way forward}

Ratoon rice as climate and resource smart technology is a practical way of increasing the rice production per unit area, time and resources such as labour, fertilizer and energy to meet the growing demand for food cereal. However, serious and systematic attempts are needed to exploit the potential and to understand the mechanisms and factors affecting ratooning ability and yield. Ratoon cropping has been found promising in specific situations like rainfed hilly areas, where the conditions are optimum for ratoon crop and not for a second rice crop or other upland crops. Ratooning in wet seasons of semi and deep water rice areas could be profitable in view of water shortage and consequent 
squeezing of growing season due climate change. Shortage of labour, fertilizer nutrients and energy are other issues which could be addressed effectively through ratooning. Since the stubbles are retained instead of being burnt as is done for a fresh second crop, it avoids consequent air pollution, draining of field after main crop harvest for sufficiently long length and subsequent shallow impounding cum aeration reduce release of GHGs viz., $\mathrm{CH}_{4}$ and $\mathrm{N}_{2} \mathrm{O}$. Development cultivars suitable for rationing through traditional and biotechnological approach are the major challenge. Another handicap is the pest. The crop being heavily pest ridden successful ratoon would be a real challenge than a separate second crop. Before making any major headway there is need for detailed study on ecological consequences and ecoeconomics. Overall, ratoon rice should be looked as an opportunity-window and solution to many emerging eco and food issues.

\section{References}

Altamarino, L. 1959. The influence of spacing on development, yield and agronomic characters of rice ratoon crop. M.S Thesis, University of the Phillipines at Los Banos, Laguna Philippines.

Anonymous. 1987. Raooning of Intan paddy in malnad and in hilly region and improved cultivation practices for high yields. UAS, bangalore, UAS, Dharwad $\&$ State Department of Agriculture, Bangalore, pp.16-17.

Anonymous. 1992. Annual Report of Agricultural Research station, Mugad, UAS Dharwad.

Anonymous. 2011. Ministry of Agriculture, Govt. of India. http:// www.indiastat.com.

Anonymous. 2012. Ministry of Agriculture, Govt. of India. http:// www.indiastat.com.
Anonymous. 2015. Agricultural Statistics at glance, Directorate of economics and statistics. Department of Agriculture and Co-operation, Ministry of Agriculture, Government of India. 3437.

Bahar, F.A. 1976. Prospects for raising productivity of rice by ratooning. MS thesis, University of the Philippines at Los Banos, Laguna, Philippines. 102 p.

Bahar, F.A. and De Datta, S.K. 1977. Prospects of increasing total rice production through ratooning. Agron. J. 69: 536- 540.

Balasubramanian, B., Morachan, Y. B. and Kaliappa, R. 1970. Studies on ratooning in rice. Growth attributes and yield. Madras Agric. J., 57(11): 565-570.

Balasubramanian, R., Balakrishnan, K. and Mancharan, S. 1992. Influence of suitable thickness, carbohydrate content and leaf senescence on ratoon rice, J. Agron. Crop Sci., 168(1): 10-12.

Bardhan Roy, S.K and Mondal, J. 1982. Ratooning ability of some photoperiod sensitive rice. IRRI Newslett., 7(6): 5.

Beachell, H.M., Scott, J.E., Evatt, N.S., Atkins, J.G. and Halick, J.V. 1961. Belle Patna. Rice J., 84(6): 24.

Bollich, C.N. and Turner, F.T. 1988. Commercial ratoon rice production in Taxas, USA, In: Rice ratooning IRRU Manila, Philippines pp.257-263.

Bond, J.A. and Bollich, P.K. 2006. Effects of pre-harvest desiccants on rice yield and quality. Crop Protection, 26: 490-494.

Chatterjee, B.N., Bhattacharya, S. and Debnath P. 1982. Ratooning of rice. Oryza, 19: 226- 227.

Chauhan, J.S., Singh, B.N., Chauhan, V.S. and Sahu, S.P. 1988. Screening of photoinsensitive summer rice (Oryza sativa L.) genotypes for ratoon cropping. J. Agron. Crop Sci., 160(2): 113-115.

Chauhan, J.S. 1988. Use of ratooning in 
hybrid rice. In: Rice ratooning. IRRI, Manila, Philippines, Pp151-154.

Chauhan, J.S., Vergara, B.S. and Lopez, F.S.S. 1985. Rice Ratooning. International Rice Research Institute. Manila.

Cuevas Perez, F.E. 1988. Rice Ratooning in the Dominican Republic. In: Rice Ratooning IRRI Manila, philippines pp 61-67.

Das, G.R. and Ahmed, T. 1982. The performance of semi-dwarf varieties of ratoon crop after summer harvest. Oryza, 19: 159-161.

De datta, S.K. and Bernasor P.C. 1988. Agronomic principles and practices of rice rationing In: Rice Ratooning IRRI Manila phlippines, pp 163-176.

Del Cruz, C.G. and Litisinger, J. A., 1988. Insect pests and their natural enemies in ratoon rice. In: Rice ratooning IRRI, Manila, Philippines pp.195-208.

Evans, L.J.C. 1957. Ratoon rice. World Crops, 9(6): 227-228.

Evatt, N.S. 1958. Stubble rice production tests. Rice J., 61(6): 1819- 40.

Evatt, N.S. 1966. High annual yields of rice in Texas through ratoon or double cropping. Rice J., 69(12): 10-12, 32.

Evatt, N.S. and Beachell, H.M. 1960. Ratoon cropping of short season rice varieties in Texas. Int. Rice Comm. Newsl., 9(3):14.

Fageria, N.K. 2007. Yield physiology of rice. J. Plant Nutrition, 30: 843-879.

FAO. 2013. Vol. XVI, 3.

Flinn, J.C. and Mercado, M.D. 1988. Economic perspectives on rice ratooning. In: Rice Ratooning IRRI, Los Baños, phlippines pp 17-29.

Flinchum, W.T. and Evatt, N.S. 1972. The effect of 2, 4-D and nitrogen on the stubble crop rice production in Texas. Rice Research in Texas. Consolidated PR 3105.

Grist, D.H. 1965. Rice. Longmans, London.
$571 \mathrm{p}$.

Haque, M. M., 1975. Varietal variations and evaluation procedures for ratooning in rice (Oryza saliva L.). MS thesis, University of the Philippines, Los Banos, Laguna, Philippines P110.

Harrell, D. L., Bond, J. A., Blanche, S., 2009. Evaluation of main-crop stubble height on ratoon rice growth and development. Field Crops Res., 114, 396-403.

Hasan, M., Kulsum, M., Akter, A., Masuduzzaman, A., Ramesha, M., 2013. Genetic variability and character association for agronomic traits in hybrid rice (Oryza sativa L.). Bangladesh J. Plant Breed. Genet., 24, 45-51.

Hou, F.W. 1983. Effects of plant growth regulators on weed community compositions, sprouting, development and grain yield of main and ratoon rice. MS thesis, University of the Philippines at Los Bahios, Laguna, Philippines. 173 p.

Hsieh, C. F. and Young., 1959. Studies on the cultivation of ratoon rice (in Chinese English summery). J. Taiwan Agric. Res., 8(3/4):21-32

Hsieh, C.F., Kao, S. and Chiang, C., 1968. Studies on the cultivation of ratooned rice. III. Effect of plowing depth and amount of fertilizar on re-viability and yield of ratooned rice [in Chinese, English summary]. J. Taiwan Agric. Res., 17(4):24-33.

Ichii, M., and Kuwada, H., 1981. Application of a ratoon to a test of agronomic characters in rice breeding. I. Variation in ratoon ability and its relation to agronomic characters of mother plant. Japanese J. Breeding. 31(3):273-278.

Ichii, M., 1983. The effect of water management on ratoonability of rice plants. Tech. BulL Fac. Agric., Kagawa Univer-sity, 34(2, Ser. 72):123-128.

Ichii, M., 1984. Studies on the utility of 
ratoon traits of rice as the indicator of agronomic characters in breeding. Mem. Fac. Gric. Kagawa University, NO. 4449p.

Ishikawa, T. 1964. Studies on the ratoon of rice plant in early cultivation [in Japanese, English summary]. Bull. Fac. Agric., Uni. of Miyazaki, Japan. 10(1): 72-78.

Iso, E. 1954. Ratoon culture of thorai varieties. In: Rice and crops in its rotation in subtropical zones. JapanFAO Association, Tokyo, Pages 197200.

Krishnamurthy, K. 1988. Rice ratooning as an alternative to double cropping in Tropical Asia, In Rice Rattoning IRRI, Los Baños Manila philippines pp 3-15

Khush, G.S. 2004. Harnessing science and technology for sustainable rice-based production systems. Proceedings of FAO Rice Conference "Rice is life". Int. Rice Comm. Newslett., 53 : 17-23.

Leopold, A.C., and Kriedemann, P.E. 1975. Plant growth and development. McGraw Hill Book Co., New York. 545 p.

Mahadevappa. M. 1988. Rice rationing practice in India In: Rice Ratooning IRRI Manila Philippines pp 69-78.

Mahadevappa, M., Gopala Reddy, T. and Nagaraju., 1988. Ratoon Rice Research in Karnataka, India In: Rice Ratooning IRRI, Manila, Philippines pp 105-109.

Mengel, D.B. and Leonards, W.J. 1978. Effects of nitrogen, phosphorus and potassium fertilization on the yield and quality of second crop Labelle rice. Annual Progress Rep., Louisiana Agric. Exp. Stn., 70: 60-62.

Mengel, D.B. and Wilson, F.E., 1981. Water management and nitrogen fertilization of ratoon crop rice. Agron. J., 73(6): 1008-1010.

Mengel, D.B. and Leonards, W. J., 1977. Effects of water management and nitrogen fertilization on second crop yield and quality (A preliminary report). Annual Progress Rep. Louisiana Rice Exp. Stn. 69:38-41.

Mew, T.W. and Fabellar, N.G 1988 Diseases and disease management in rice ratoon crops In: Rice Ratooning IRRI Manila, Philippines. Pp. 209-217.

Nagai, I. 1958. Japonica rice, its breeding and culture. Yokendo Ltd., Tokyo. 843 p.

Nagaraja, A. and Mahadevappa, M., 1986. Quality of main and ratoon crop seeds of rice. Oryza, 23: 118-122.

Nagaraja, A.K., Chakaravarthy and Mahadevappa, M. 1988. Disease and insect pests and their control in rice rationing systems In Rice Ratooning IRRI Manila Philippines pp 233-238.

Nakano, H. and Morita, S. 2007. Effects of twice harvesting on total dry matter yield of rice. Field Crops Res., 101: 269-275.

Niyaki, S.A.N., Radjabi, R. and Allahyari, M.S. 2010. Social Factors Critical for Adoption of Biological Control agents Trichogramma spp. Egg parasitoid of rice stem borer Chilo suppressalis in North of Iran, American-Eurasian J. Agri. Environ. Sci., 9(2): 133-139.

Oad, F.C., Cruz, P.S., Memon, N., Oad, N.L. and Hassan, Z.U., 2002. Rice ratooning management. Pak. J. Appl. Sci., 2(1): 29-35.

Oliveira, A.B.De. and Neto, S.A. 1979. Producao da soca decultivares de arroz diferentes epocas de semeadura, nas condicocs do Norte Fluminense, Comunicado Tecnico, (Estacao Experimental de Campos) 31: 1-3.

Palchamy. A., Purushothman, S. and Rajgopal, A., 1990. Effect of stem thickness and carbohydrate content on ratoon rice yield, Int. Rice Res. News Lett., 15(2): 10.

Pandang, M.S., Zainal, A.S. and Bahar, F.A. 1977. Time of planting "gogo rancah" 
on lowland fields in South Sulawesi. The Third Workshop on Cropping systems, CRIA, IRRI, Bogor, Indonesia.

Paroda, R.S. 1998. ICAR Reporter. Indian Council of Agric Res., New Delhi. pp.123.

Prakash, K.S., Krishnamurthy, K., Panchal, Y.C. and Prakash, B.G. 1988. Production practices for ratoon rice in Tungabhadra river project of Karnatak In: Rice Ratooning IRRI Manila, philippines, pp 97-103.

Prakash, K.S. and Prakash, B.S. 1988. Screening of rice varieties for ratoon ability in Tunga Bhadra River Project of Karnataka. P256-269. In: Rice Ratooning. IRRI, Philippines.

Prashar, C.K.R. 1970. Some factors governing rice-ratoon yields. Plant and Soil, 32: 540-541.

Parago, J.F. 1963. Rice ratoon culture. Agric. Ind. Life, 25(8): 1545- 47.

Parago, J.F. 1963b. Rice ratooning culture. Agric. Ind. Life, 25(8): 1545.

Plucknett, D.L., Escalada, R.G. and Dela Peng. 1978. Crop Ratooning. J. Ser. 2266 of the Hawaii Agril. Expt. Station, Honolulu, Hawaii, UAS, 40p.

Poehlman, J.M. 1976. Breeding field crops (Rice). $2^{\text {nd }}$ Edition, Westcot, Connecticut: AVI Publishing Co.

Quddus, M.A. 1981. Effect of several growth regulators, shading and cultural management practices on rice ratooning. MS thesis, University of the Philippines at Los Banos, Laguna, Philippines. $100 \mathrm{p}$.

Ramos, M.G., and Dittrich, R.C. 1981. Effect of height of cutting at rice harvest on the yield of the ratoon crop. Pages 137140 in An IIA Reuniao Da Cu!tura De Arroz Irrigado, Illus. Pelotas, Uepae, Brazil.

Reddy, V.R. and Pawar, M.S. 1959. Studies on ratooning in paddy. Andhra Agric. J., 6(2): 70-72.
Reddy, T.G., Mahadevappa, M. and Kulkarni, K.R. 1979. Ratoon crop rainfed rice. Int. Rice Res. Newsl., 4(6): 22-23.

Reddy., T.G. and Mahadevappa, M. 1988. Rice Ratoon management in the hilly region of Karnataka In Rice ratoonin IRRI Manila, philippines pp.87-96

Rehman, H.U., Farooq, M. and Basra, S.M.A. 2013. Rice ratooning: a technology to increase production. Pakissan.com (online).

Rejesus, R.M., Samarendu, M. and Balagtas, J.V. 2012. Forecasting global rice consumption.

Rosamma, C.A., Karunakara, N.K., Chandrika, P. and Nair, N.R. 1988. Weight and germination of main and ratoon crop seeds, Int. Rice Res. News letter, 13(4): 4.

Roy, S.K.B., Mondal, J., Chatterjee, B.N., Bhattacharya, S., Debnah, P. and Mondal, B., 1988. Potential for rice ratooning in eastern India with special reference to photoperiod Sensitive rices for deep water areas In Rice Ratooning IRRI Manila, Philippines pp.135-142.

Samson, B.T., 1980. Rice ratooning: effects of varietal type and some cultural management practices. MS thesis, University of the Philippines at Los Banos, Laguna, Philippines P 116.

Sanchez, N.P. and Cheaney, R.L. 1973. Preliminary results on ratoon planting of the variety Cica 4. Programa Nacional de Arroz. Reunion Annual V. ICA Cerete. p. $129-132$.

Santos, A., Fageria, N. and Prabhu, A., 2003. Rice ratooning management practices for higher yields. Commun. Soil Sci. Plant Anal., 34: 881-918.

Saran, A.B. and Prasad, M. 1952. Ratooning in paddy. Curr. Sci., 21(8): 223-224.

Setty. T.K.P., Parameshwar, N.S. and Mahadevappa, M., 1993. Reponse of Mukthi (TMI) ratoon to nutrition in coastal Karnataka, India, Int. Rice Res. 
Notes, 18(1): 42-43.

Srinivasan, K. 1988. Effect of N application timing of ratoon rice. IRRN, 14: 16p.

Srinivasan, K. and Purushothman, S. 1990. Effect of plant spacing on ratoon rice performance, Int. Rice Res. News Lett., 15(4): 21.

Sompaew, V. 1979. Stand establishment techniques in direct-seeded dryland rice. $\mathrm{Ph} \mathrm{D}$ thesis, University of the Philippines at Los Bafios, Laguna, Philippines. $182 \mathrm{p}$.

Sun Star. 2013. (newspaper) 17 July 2013. 5000 hectares of rice land in Leyte identified for ratooning.

Sun Xiaohui, Zhang Jing guo and Liang Yujiu. 1988. Ratoonong with rice hybrids. P15-161. In: Rice Ratooning. IRRI, Philippines.

Szokolay, G. 1956. Ratooning of rice on the Swaziland Irrigation scheme. World Crops, 8(2): 71-73.

Vergara, B.S., Lopez, F.S.S. and Chauhan, J.S. 1988. Morphology and physiology of ratoon rice. IRRI, Philippines Pp1314.

Vargheese, T.J. and Patil, B.P. 1991. yield of wet season ratoon rice in Konkan region Maharashtra, India, Int. Rice Res. News Lett., 16(3): 12.

Volkova, N.P. and Smetanin, A.P. 1971. On ratooning characters of rice $\mathrm{cv}$. adapted to the Kuban region. Byulleten
Nauchno-Tekhnicheskoi Informatsii, usesoyuznyi Nauchno-Issledovatel' Skii nstitut Risa 3: 21-24. From Referativnyi Zhurnal, 55(3): 345.

Votong, V. 1975. The effect of time of drainage and time of rewatering on the yield of ratoon rice. MS thesis, University of Sydney, Australia.

Xiong, H., Fang, W. and Tan, Z.B. 1991. Effect of number of auxillary buds and main crop cutting time on ratoon crop yield. Int. Rice Res. News Lett., 16(1): 19.

Yang, K.C., Sun, S.W. and Long, C.Y. 1958. A. study of regeneration rice. [in Chinese, English Surnmary) J. Acta Agric. Sin., 9: 107-133.

Yang, S.J. 1940. The cultivation of regenerated rice and its future in Hunan and Szechuan [in Chinese, English summary] Nung Pao 5: 46-52. Pages 110 in Ratoon cropping in swampy or wetland rice (From 1940-65). Commonwealth Bureau of Pastures and Field Crops.

Zhang Jing Guo. 1991. Hybrid rice ratoon exploited in Sichan, China. IRRN 16: (5).

Zandstra, H.G. and Samson, B.T. 1979. Rice ratoon management. Paper presented at the International Rice Research Conf., $10 \mathrm{p}$.

\section{How to cite this article:}

Negalur, R.B., G.S. Yadahalli, B.M. Chittapur, G.S Guruprasad and Narappa, G. 2017. Ratoon Rice: A Climate and Resource Smart Technology. Int.J.Curr.Microbiol.App.Sci. 6(5): 16381653. doi: https://doi.org/10.20546/ijcmas.2017.605.179 